\title{
Ecommerce Policy Conundrum Disrupting Consumer Efficacy Euphoria and Ease are Becoming the Elucidated Predictors in The Emerging Lifestyle of Indian Online Purchasing Diaspora.
}

\author{
R. Vijaya Baskaran
}

\begin{abstract}
Physical store based need fulfillment and shopping as physical experience has been largely challenged and continuously reducing the demarcation between offline and online buyer preferences globally and especially in a thickly populated country like India the models are surprising evolving into a well favoured and highly accepted societal upheaval more precisely in the recent past. Humpty number of want factors initially drove the market with tough irresistible bargaining saw the cash burn minimized and brand supremacy reigned in .Things started looking apparently different in a deciduous to deadly adoption rates blistering with woven choices and solid preferences backed by quality decisions making Indian ecommerce market a formidable dominant in the years to come. The culminating reasons embedded in the psycho-socio-cultural fabric rather than the pure cost and scarcity based simple need fulfillment. The consumer journey just began riddled with information fuelled buyer power stoically sewn into the age old mortared models. Ecommerce marketspace is filled with unappalled expectations where companies are stoically gunning for lifetime customer value and virtual anecdotes leading to unquestionable loyalty might be in the chosen segments either by the firm or by the end user with the extensive deployment of technology in forecasting and fulfilling existing and emerging needs of the digital users.
\end{abstract}

Index Terms: online buyer, fulfilment centers, drones, last mile delivery, communities, connectivity and analytics

\section{INTRODUCTION}

Indian ecommerce bandwagon is getting into its tipping point after having literally mowed down by the dot com bust twenty years ago where all bubbles could not test their mettle and dripped down into oblivion throwing the entire gamut of online retail industry in a tricky position whether it was a sort of stop gap preference more to say as a fashion to fad syndrome. Developed markets like USA ,UK and few other European nations studiously adhered to the model since the massive investments in technology could well be afforded by

Revised Manuscript Received on 30 July 2019.

* Correspondence Author

Dr.R.VijayaBaskaran*, Principal, East Point College of Higher Education Bangalore Karnataka

(C) The Authors. Published by Blue Eyes Intelligence Engineering and Sciences Publication (BEIESP). This is an open access article under the CC-BY-NC-ND license http://creativecommons.org/licenses/by-nc-nd/4.0/ them in a transient manner where rest of the world was happy to tranquilise on offline physical model which was less complicated and more freedom guaranteeing sustainable experiences based on wider purchasing options. India was also experimenting on the static to interactive web based models of ecommerce where the absence of conspicuous credibility threw an element of uncertainty in growth and adoption. Indian online population has not even started their delve into the realms of ecommerce potential where the sole reason being the slow adoption of Internet technology which served as the cradle for ecommerce growth and popularity. The beginning time was EDI (electronic data interchange) and EFT (electronic fund transfer) since 1998 fuelled the ecommerce engine in India whereas China was at least ahead in those days and started during 1990-93 period and now average purchase online per year per user is US\$880 and it is close to US $\$ 890$ billion cornering $48 \%$ of global ecommerce market. The humble starting was from www.8848.com now dominated by JD.Com and T-mall besides cross border ecommerce options driven by the unique double 11 shopping festival fondly known as singles day to nearly half a dozen key festivals to drive proliferating brands into Chinese consumer homes and the obvious shrinking of $\mathrm{O} 2 \mathrm{O}$ (offline to online) and $\mathrm{B} 2 \mathrm{C}$ is also happening which is not witnessed in other markets. The contention here is not attempting to deduce the differential adoption and growth indicators of both the markets which has half of the active internet users but to depict the astounding gaps and lack of stimulants on the people processing tossed haphazardly between tangible and intangible ends of service spectrum which looks visibly unstable in the long run. Recent findings indicate in the Indian ecommerce market around 50 million users muted their interest in online purchases ending up with little more than US $\$ 50$ billion revenues in 2018-19. Well adding up more by way of subscription mode like amazon prime is also getting procrastinated beyond unintentional gains in the long run. At an average monthly shipments between 1.3 to 1.5 million per day Indian E-commerce stalwarts go for a whopping 3.5 to 4.5 million shipments during festival sales termed as Big Billion day and Great Indian festival by flipkart and amazon respectively say beginning October and extending up to January new year sale period. 


\section{Ecommerce Policy Conundrum Disrupting Consumer Efficacy Euphoria and Ease are Becoming the Elucidated Predictors in The Emerging Lifestyle of Indian Online Purchasing Diaspora.}

In 2017 festive season the overall merchandise sold is estimated to be around US\$2.4 to 2.7 billion. Invariably to address the logistics side around 45000 new staff per the popular players and totally around 400000 staff are recruited during this season bonanza to manage the surging volume of 3.5 million shipments a day during the prime slots and 2.5 million on the other days of festival sale. Every year since 2012 we are witnessing increased sales being clocked by ecommerce companies both big and small even boutique firms and the concept has penetrated innocuously into tier-II and tier-III cities in the recent past.

\section{SIGNIFICANCE OF THE STUDY}

Indian online user bases is ostensibly getting acclimatized by ever increasing concerns on trust, quality, review and repeat purchases on a thumping jumping sales around $70 \%$ by value lamenting the offline conventional and congenial mode threw innumerable unanswered becoming a global one but for us after the prominent precursor of technological upheaval ecommerce companies are largely opting to ring fence their customer base which wobbles during festivities and obviously beyond comprehensive altruism reasons. Basically the unwilling compromises extended by the online servitude could largely been the cause. Was it merely a thrill of being an online buyer or looking for value based activities which hitherto would be largely sustaining? The more alleviating the bigger the buyer base conundrum is witnessed in the recent past.

\section{REVIEW OF LITERATURE}

Existing challenge facing Internet retailers on the stickiness and conversion lies in the area of loyalty of the customer loyalty aka e-loyalty which from the perspective of noted authors R. Anderson and Srinivasan (2003), could be discerningly defined as 'the customer's favorable attitude toward an electronic business offering ultimately ending with the repeated purchasing patronized behaviour' ( $p$. 125).Adding on the same view by Wang, Head, and Archer (2000), for instance reasserted that any long-term sustainability and profitability of online marketplaces/players could only be probably achieved when Internet retailers build inimitable touch points to embrace the challenge of fostering online customer loyalty. In addition to this, a number of varied authors have formidably argued that the very understanding how to develop loyalty is unequivocally important to all ecommerce retailers (Goode \& Harris, 2007; Reichheld, 2001; Reichheld \& Schefter, 2000; Zeithaml, Parasuraman, \&Malhotra, 2002). Moretti L, Di Pellegrino G (2010) in their article observed that disgust, a moral emotion associated with norm violation, was also been largely implicated in ultimatum rejections and from the way in which Pillutla MM, Murnighan JK (1995) argued that the prevailing egocentric biases imply that individuals commonly have stable social preferences which is the resultant of networking effects in the social electronic word of mouth and the resultant switch between justice principles is practiced in order to maximize their payoff in each of the available and every scathing situation in fact be considered acting presumably in order to appear or to be perceived as fair simply being a means to avoid rejection) It is also true that many companies strive to build customer loyalty as one of the ways to increase and sustain profits as well as reduce costs (Reichheld, 1993; Agustin and Singh, 2005; Watson et al., 2015) As a relationship portrayal method it is conveniently presumed that when customers are loyal, companies invariably end up investing less in sales and marketing to attract and retain new customers (Reichheld, 1993). In other word the valuable organizational resources necessarily to be deployed in different ways such as developing and improving products to focus on specific customer needs which may vary from segment to segment in a multi-cultural context. Research in this aspect revealed that the service performance and the resulting customer relationships mostly influence the customer loyalty factors and reduce the brand switching too (Augustin and Singh, 2005; Čater and Čater, 2010; Rafiq et al., 2013; Watson et al., 2015) why because in joining a e-marketspace, scouting buyers can always look for meaningful interaction with sellers online say in portal or vertical vis-à-vis clearly and effectively communicate their needs and shop for goods and services at competitive prices anytime and from anywhere (Dan, 2014). In turn sellers could also receive benefits such as reaching a big group of individual consumers with minimum promotion and achieving deeper market penetration and consistent expansion and ultimately saving marketing costs (Kim and Ahn, 2006). Considering the relationship strategies the variables like financial bond, emotional bind ,scoialbond and structural bond researchers have unearthed several relational factors that are truly the noted antecedents of customer loyalty (Palmatier et al., 2006; Watson et al., 2015).The key ingredient on those parameters being 'Trust' a less understood and more debated factor in all digital marketing science is the enduring factor resulting in owning the brand and getting more inter twined also in the terms of Barnes et al., 2011; Morgan and Hunt, 1994 it is the factor for building and maintaining any sort of relationship with customers also it is reaffirmed as a determinant to exhibit willingness to take any purchasing risk and could become lot more vulnerable to the actions of another (Mayer et al., 1995).Trust becomes inherently more intrinsic in extending online affiliation in terms of brand association and brand assertion when other factors can marginally influence(vijayabaskaran,2017). Moreover it is also identified by Granovetter, 1973 that often an individual's position within the associated network and the extent of his or her ties exerted within the peer group in other words is the key investment to provide the social capital expressed as access to information and associated transactional virtues. Similarly from the brand or sellers point of view that the buyer turns trustworthy, then they are more likely to disseminate product or service related knowledge in a deterministic manner (Ragatz et al., 1997). Such kind of suppliers who started their trust towards the buyer may step up intensely their attempt to do joint planning and further take responsibility together (Johnston et al., 2004) 
in simplifying tasks and targets resulting in notable invest in buyer-centric technology and willing to share proprietary technology too (Yeniyurt et al., 2014) The study by (Agustin and Singh, 2005; Čater and Čater, 2010; Pan et al., 2012; Rafiq et al., 2013; Reichheld, 1993; Watson et al., 2015 ) showcased the that relationship characteristics such as trust and satisfaction intrinsically influence customer loyalty to a definite extent. Then coming to commitment that is will greater amount of trust and satisfaction end up long lasting brand affiliation, preference and commitment here the study by (Moorman, Zaltman, and Deshpande 1992) gave insightful inference stating that commitment is an enduring desire towards maintaining and managing valued relationship and attempting to link loyalty satisfaction and commitment to value dispositions stating that trust is an outcome of understanding partners' reliability and integrity(Morgan and Hunt 1994, p. 23).It clearly disassociate itself from mere physical transactions happening in the digital space but virtuality how far getting influenced by cognitive perceptions which are instrumental in building loyalty(Baskaran, V., R. 2018) Ideally concurring the element of trust is much more looked upon in digital market spaces since online services and products invariably are not immediately verifiable ( Gefen, D and Straub 2004) and need to be strengthened by its very nature of building and enhancing loyalty aspects as a part of product offerings, service associations so on and so forth in the long run which the leading etailers in the globe have witnessed as the metrics of success. Considering the life time value of the consumer the longer customers maintain their relationship with a firm the chances are more for them to the value they generate (Reichheld, 1996) and inturn firm can strongly enchant their relationship. Brand equity is also adding comprehensive value to business by bringing the competitive advantages into existence (Torres et al., 2015) thereby adhering to customer bonding and relationship spectrum. Finally literature concludes that brand loyalty is considered one of the most critical factors in determining the value that the customer provides (Maicas et al., 2006) thus pinning it exactly on trust and commitment.

\section{NEED AND OBJECTIVES OF THE STUDY}

The most intrigued feature of all online marketplace models were the ability to convert the prospective who chooses and indulges in online purchasing habits either out of sheer thrill or obtaining value based deals or else trying to level up his due efforts of finding the most satisfying purchases after due diligence and reinforced behavioural balances in the course of time. This study also eyes into those factors marginally as well as deeply ingrained in ones backdrop while choosing the particular product with particular seller on a count me on basis.

\section{RESEARCH METHODOLOGY}

This section primarily addresses the sampling plan, sampling method, sampling frame, data collection sources and methods, statistical procedures deployed to analyze the collected and sorted data and ending with the limitations of the study as a research perspective. Ostensibly to satisfy both objectives say primary and secondary a detailed questionnaire with balanced cues illustrating both quantitative and qualitative analysis was designed to interview the online consumers who have been associated with digital practices at least for a decade in India. Consumer Research is basically a systematic and continuous method of defining a problem mostly assertive in nature, collecting and compiling the facts and subsequently analyzing them into prospective domains ending up drawing conclusive descriptions in a deductive or inductive reasoning mode as the case may be. Research methodology is a tool to systematically analyse and meaningfully relate the repository of data pertaining to the problem of the study. The inbuilt nature to throw more light into those constructs chosen and to describe the various steps followed and that all generally adopted by a researcher in studying his research problem along with the logic behind them. The research methodology adopted in this investigation is grouped under the following headings for the sake of explanation such as 1. Research design 2. Population 3. Sample Design 4. Data Collection

Research design: Richey (2007) admits scholarly that a good Research design should handle with the issues such as selecting the respondents more often knowledgeable about the issue since many a times we come across the audience though have data but showing less or no interest to share their cognitive aspirations since it may not look like well documented (Baskaran, V., R. 2018) and thereafter ending with data collection are the key activities that comprise as well as complete this research process always leading it to subsequent study later to assimilate facts. According to Burns and Bush (2006) the very nature of exploratory research design is involved as gathering information in an informal and unstructured manner soliciting information describing the nature and scope of any study. The exploratory research design is accepted as a known means when the researchers know less information and data about the opportunity or an issue. Exploratory research design is nevertheless not limited to one specific paradigm or any chosen model rather predictors but may be used either qualitative or quantitative approaches as the nature and observation of the variable. Here the research design was formulated which guided the collection analysis and interpretation of data. Here the exploratory research design was followed and survey was done with the help of a structured non-disguised questionnaire illustrating the factors with expected knowledge and awareness and must have been widely discussed in the organizational hierarchies in house.

Population: The population for the study consisted of 307 shortlisted respondents after circulating the questionnaire in electronic and personal survey format to little more than 400 . It is carried out in the city of Bangalore the well-known IT Capital of India having a population of 10 million and the geography is divided into 5 geographical segments like Bangalore south, Bangalore North, Bangalore East, Bangalore west and Central business district of Bangalore. The reason to choose this is it represents all sort of people representing almost all states of India. As per the study available Bangalore has $56 \%$ population outside this state and $44 \%$ the locals. 


\section{Ecommerce Policy Conundrum Disrupting Consumer Efficacy Euphoria and Ease are Becoming the Elucidated Predictors in The Emerging Lifestyle of Indian Online Purchasing Diaspora.}

\section{Data Collection:} non-disguised questionnaire circulated to 410 respondents and filtered to arrive at 307 completed answered questionnaire which had efficiently served its intention of attempting to suggest or lead or imply since sensitive responses are to be captured was the main intention of this research. Most of these questions designed with closed ended types of course with a few open ended questions in support of strategically loaded factors assimilated in a conspicuous manner. These selected respondents had long association with online purchases some even dating back 10-15 years ago which was in the very beginning of the Indian Ecommerce Era. The strategic factors chosen is also verified with the respondents meaning that they are very well aware and understand the context in which such questions are raised. The challenge here was remembrance and recollecting those critical incidents which really mattered at those time of purchases could not be expressed with same depth and impact owing to very nature of time elements involved but the very recent experiences were truly impacting the overall preference and long help assumptions of these respondents. The interesting part is when somebody held an unassailable belief that the particular product procured with lesser facts have fulfilled or not fulfilled their expectations the strength of their association or switching with the brand or product is seemingly consistent.

\section{ANALYSIS AND INTERPRETATION}

Before proceeding with analysis the idea taken in this research are (i) Consumer efficacy (ii) Consumer euphoria and (iii) consumer ease and the respective factors are shown here .

\begin{tabular}{|c|c|}
\hline $\begin{array}{c}\text { Consumer } \\
\text { Efficacy }\end{array}$ & $\begin{array}{c}\text { Hyper Personal ,GMV, Trendy, Quality, } \\
\text { Reminder }\end{array}$ \\
\hline $\begin{array}{c}\text { Consumer } \\
\text { Euphoria }\end{array}$ & $\begin{array}{c}\text { More Choices Opt reviews, Peer support, Own } \\
\text { Brand, Near store pick up, Easy payment }\end{array}$ \\
\hline Consumer Ease & $\begin{array}{c}\text { Impulsive, Timely discount, same day delivery, } \\
\text { last mile connectivity }\end{array}$ \\
\hline
\end{tabular}

\section{Exploratory Factor Analysis}

\section{Total Variance}

Explained

\begin{tabular}{|l|c|c|c|c|c|c|c|c|c|}
\hline $\begin{array}{l}\text { Compo } \\
\text { nent }\end{array}$ & \multicolumn{3}{|c|}{ Initial Eigenvalues } & \multicolumn{3}{c|}{$\begin{array}{c}\text { Extraction Sums of Squared } \\
\text { Loadings }\end{array}$} & \multicolumn{3}{c|}{$\begin{array}{c}\text { Rotation Sums of Squared } \\
\text { Loadings }\end{array}$} \\
\cline { 2 - 10 } & Total & $\begin{array}{r}\text { \% of } \\
\text { Variance }\end{array}$ & $\begin{array}{c}\text { Cumulat } \\
\text { ive \% }\end{array}$ & Total & $\begin{array}{c}\text { \% of } \\
\text { Variance }\end{array}$ & $\begin{array}{c}\text { Cumulativ } \\
\mathrm{e} \%\end{array}$ & Total & $\begin{array}{c}\text { \% of } \\
\text { Variance }\end{array}$ & $\begin{array}{c}\text { Cumulativ } \\
\text { e \% }\end{array}$ \\
\hline 1 & 4.785 & 25.183 & 25.183 & 4.785 & 25.183 & 25.183 & 4.773 & 25.119 & 25.119 \\
2 & 3.075 & 16.187 & 41.370 & 3.075 & 16.187 & 41.370 & 2.774 & 14.597 & 39.716 \\
3 & 2.484 & 13.072 & 54.442 & 2.484 & 13.072 & 54.442 & 2.501 & 13.162 & 52.878 \\
4 & 2.101 & 11.056 & 65.498 & 2.101 & 11.056 & 65.498 & 2.362 & 12.431 & 65.309 \\
5 & 1.647 & 8.669 & 74.168 & 1.647 & 8.669 & 74.168 & 1.683 & 8.859 & 74.168 \\
6 & .951 & 5.005 & 79.173 & & & & & & \\
7 & .777 & 4.089 & 83.262 & & & & & & \\
8 & .668 & 3.517 & 86.778 & & & & & & \\
9 & .568 & 2.988 & 89.766 & & & & & & \\
10 & .408 & 2.147 & 91.913 & & & & & & \\
11 & .343 & 1.808 & 93.721 & & & & & & \\
12 & .336 & 1.768 & 95.488 & & & & & & \\
13 & .257 & 1.355 & 96.843 & & & & & & \\
14 & .174 & .917 & 97.760 & & & & & & \\
15 & .133 & .702 & 98.462 & & & & & & \\
16 & .097 & .510 & 98.973 & & & & & & \\
17 & .078 & .412 & 99.385 & & & & & & \\
18 & .066 & .349 & 99.734 & & & & & & \\
19 & .051 & .266 & 100.000 & & & & & &
\end{tabular}

Extraction Method: Principal Component Analysis
Primary data was collected with the help of a structured drawing inputs in an indirect discrete manner never

Rotated Component Matrix ${ }^{3}$

\begin{tabular}{|l|l|l|l|l|l|}
\hline \multirow{2}{*}{} & \multicolumn{1}{|l|}{ Component } \\
\cline { 2 - 6 } & 1 & 2 & 3 & 4 & 5 \\
\hline HyperPersonal & -.042 & .902 & -.043 & .054 & -.043 \\
GMV & .013 & .900 & -.045 & .035 & -.032 \\
Trendy & .051 & .825 & .032 & .047 & .024 \\
Quality & .014 & .623 & .097 & .077 & -.048 \\
Impulsive & .904 & -.008 & -.002 & .055 & -.041 \\
Reminder & .908 & -.023 & -.038 & .012 & -.043 \\
Timely Discounts & .938 & -.017 & .000 & .000 & -.050 \\
SamedayDelivery & .938 & .020 & .003 & .021 & -.001 \\
Last mile & .877 & .028 & -.004 & -.012 & .040 \\
Ease of Return & .765 & .029 & -.020 & .009 & .085 \\
Easy Payment & -.002 & .039 & .905 & .027 & -.037 \\
NearStorePickup & -.010 & -.006 & .939 & .022 & -.049 \\
Own Brand & -.029 & .044 & .876 & -.051 & .035 \\
Peer Support & -.006 & -.031 & -.003 & -.014 & .889 \\
Opt Reviews & -.022 & -.008 & .003 & .020 & .890 \\
More Choices & -.027 & .120 & .029 & .913 & -.020 \\
Loyalty & .038 & .099 & -.018 & .929 & -.040 \\
BetterThanOffline & .068 & -.015 & -.039 & .763 & .029 \\
customercare & -.058 & .221 & .120 & .252 & -.270 \\
\hline Extraction Method: Principal Component Analysis. \\
Rotation Method: Varimax with Kaiser Normalization. & \\
a. Rotation converged in 4 iterations.
\end{tabular}

able: 1.2 Component Extraction

\begin{tabular}{|c|c|c|c|c|c|c|c|}
\hline $\begin{array}{l}\text { Compo } \\
\text { nents }\end{array}$ & \multicolumn{2}{|c|}{$\begin{array}{c}\% \text { of } \\
\text { Variance }\end{array}$} & \multicolumn{3}{|c|}{$\begin{array}{l}\text { Variable included in } \\
\text { the factor }\end{array}$} & & oading \\
\hline \multirow[t]{6}{*}{1} & \multirow{6}{*}{\multicolumn{2}{|c|}{25.119}} & \multicolumn{3}{|c|}{ Impulsive } & & .904 \\
\hline & & & \multicolumn{3}{|c|}{ Reminder } & & .908 \\
\hline & & & \multicolumn{3}{|c|}{ Timely discounts } & & .938 \\
\hline & & & \multicolumn{3}{|c|}{ Same day delivery } & & .938 \\
\hline & & & \multicolumn{3}{|c|}{ Last mile } & & .877 \\
\hline & & & \multicolumn{3}{|c|}{ Ease of Return } & & .765 \\
\hline \multirow[t]{4}{*}{2} & \multirow{4}{*}{\multicolumn{2}{|c|}{14.597}} & \multicolumn{3}{|c|}{ HyperPersonal } & & .902 \\
\hline & & & \multicolumn{3}{|l|}{ GMV } & & .900 \\
\hline & & & \multicolumn{3}{|l|}{ Trendy } & & .825 \\
\hline & & & \multicolumn{3}{|l|}{ Quality } & & .623 \\
\hline \multirow[t]{3}{*}{3} & \multirow{3}{*}{\multicolumn{2}{|c|}{13.162}} & \multicolumn{3}{|c|}{ Easy payment } & & .905 \\
\hline & & & \multicolumn{3}{|c|}{ Near store pickup } & & .939 \\
\hline & & & \multicolumn{3}{|c|}{ Own Brand } & & .876 \\
\hline \multirow[t]{3}{*}{4} & \multirow{3}{*}{\multicolumn{2}{|c|}{12.431}} & \multicolumn{3}{|c|}{ More choices } & & .913 \\
\hline & & & \multicolumn{3}{|l|}{ Loyalty } & & .929 \\
\hline & & & \multicolumn{3}{|c|}{ Better than offline } & & .763 \\
\hline 5 & & & Peer Sup & port & & & .889 \\
\hline & & & Opt Revi & ews & & & .890 \\
\hline & Cluster & & Error & & $\mathbf{F}$ & & Sig. \\
\hline & $\begin{array}{c}\text { Mean } \\
\text { quare } \\
\end{array}$ & $\mathrm{df}$ & Mean Square & df & & & \\
\hline yperPersonal & 76.454 & 3 & 1.625 & 303 & 47.0 & & .000 \\
\hline & $\begin{array}{l}72.050 \\
74.263\end{array}$ & $\begin{array}{l}3 \\
3\end{array}$ & $\begin{array}{l}1.623 \\
1.749\end{array}$ & $\begin{array}{l}303 \\
303\end{array}$ & $\begin{array}{l}44.38 \\
42.4\end{array}$ & & .000 \\
\hline $\begin{array}{l}\text { lity } \\
\text { lity }\end{array}$ & $\begin{array}{l}74.503 \\
17.514\end{array}$ & 3 & 1.584 & 303 & $\begin{array}{l}42.45 \\
11.0\end{array}$ & & .000 \\
\hline Impulsive & 205.775 & 3 & 1.067 & 303 & 192. & & .000 \\
\hline Reminder & 217.543 & 3 & 1.001 & 303 & 217. & & .000 \\
\hline Timely Discounts & 161.953 & 3 & .808 & 303 & 200. & & .000 \\
\hline SamedayDelivery & 182.325 & 3 & .988 & 303 & 184. & & .000 \\
\hline mile & 108.736 & 3 & .992 & 303 & 109. & & .000 \\
\hline Ease of Return & 84.370 & 3 & 1.357 & 303 & 62.1 & & .000 \\
\hline Easy Payment & 24.984 & 3 & 2.002 & 303 & 12.4 & & .000 \\
\hline rStorePickup & 19.548 & 3 & 2.010 & 303 & 9.72 & & .000 \\
\hline Brand & 20.541 & 3 & 2.023 & 303 & 10.1 & & .000 \\
\hline Peer Support & 5.306 & 3 & 2.198 & 303 & 2.41 & & .000 \\
\hline Opt Reviews & 5.613 & 3 & 2.382 & 303 & 2.35 & & .000 \\
\hline More Choices & 36.874 & 3 & 1.684 & 303 & 21.8 & & .000 \\
\hline Loyalty & 41.936 & 3 & 1.854 & 303 & 22.6 & & .055 \\
\hline BetterThanOfflin & 16.520 & 3 & 1.857 & 303 & 8.89 & & .072 \\
\hline customer care & 26.486 & 3 & 2.071 & 303 & 12.78 & & .061 \\
\hline
\end{tabular}

The researcher's' cautious claim is always that the $F$ tests are meant to be employed for descriptive purposes since the clusters have been chosen rather to maximize the differences among the idented cases in the chosen classers. Obo ho construed as tests of the hypothesis the no cluster means are equal.

In the anova Table 1.3 the factors like Loyalty ,Better than offline and Customer care were found to be not significant. Hence the next analysis these 3 attributes are not included for SEM model.

Published By:

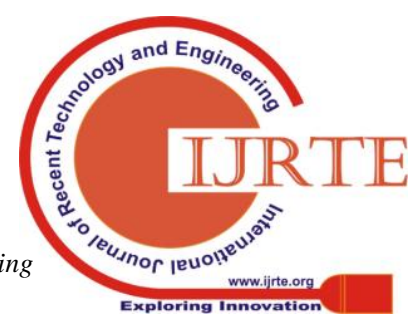




\section{Structural Equation Modelling}

Structural equation models otherwise known as simultaneous equation models refer to a set of multiequation systems which comprise of continuous latent variables each designed or assumed to represent a concept in other words construct too. We can also see that as an interrelated system of regression equations having multiple indicators and in which the measurement error is also considered when estimating or postulating the relationships. In yet another perspective these are also factor analysis models in which factor loadings are restricted to zero and the researcher does allow these factors to influence each other either directly and indirectly. From the research perspective SEM have been widely found its origin in pure and applied psychology (Cole and Maxwell, 2003; Bentler and Weeks,1980; Bentler and Tanaka, 1982; Anderson and Gerbing, 1987), also in the study of econometrics model (Krishnakumar and Nagar, 2008; Muthen, 1983), in describing social sciences and quantitative behavioral sciences ( Netemeyer and Bentler, 2001; Bauer, 2003; Anderson, 1987; 2008) and management theory (Gerbing and Anderson, 1984, 1988; Anderson, 1987; Bagozzi and Fornell, Also reiterated many times like fundamental distinction can be made between the use of structural equation modeling for theory testing and development versus predictive application (Fornell and Bookstein, 1982; Joreskog and Wold, 1982) When we attempt to test a theory using SEM after formally defining the theoretical constructs then while attempting to estimate each concept or construct we call this methodology as the confirmatory factor analysis (Holzinger, 1944; Jöreskog 1969) which is different from the exploratory factor analysis. But here we conduct exploratory factor analysis first to primefacie understand the nature of these constructs then possible proceeding with linking them or inter relating them based on the hypothesis and assumptions depicting in what is called as path diagrams.

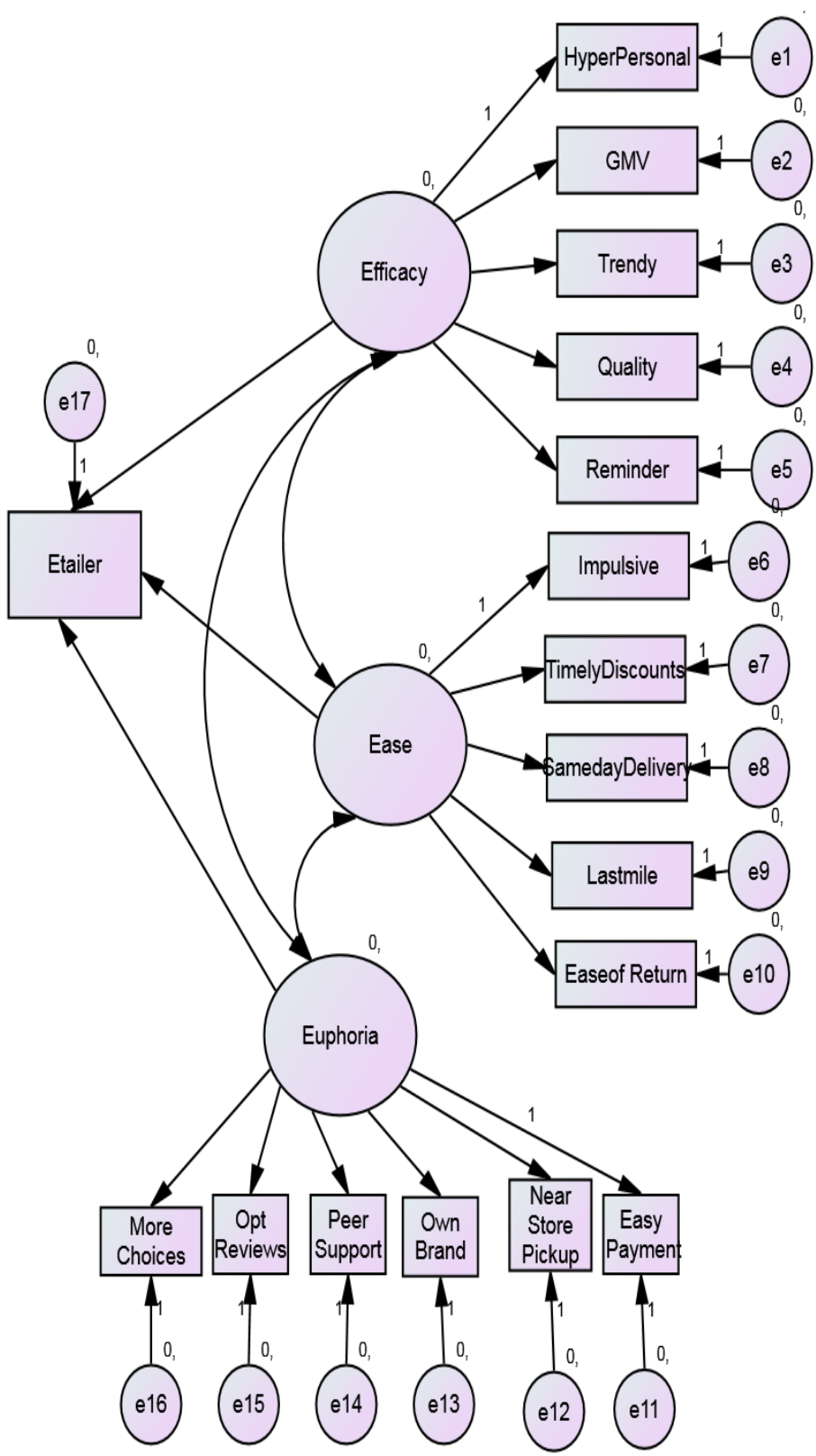

From the SEM analysis the findings are shown in Table 1.4 indicating moderately a good fit between the chosen variables and the Fitness Indices implying the validity of the model.

Table 1.4 Fitness Indices
\begin{tabular}{|c|c|c|c|c|c|c|c|c|}
\hline & CMIN/DF & RISEA & AGFI & GFI & CFI & NFI & IFI & TLI \\
\hline $\begin{array}{c}\text { Default } \\
\text { Model }\end{array}$ & 4.156 & 0.027 & 0.902 & 0.911 & 0.9 & 0.92 & 0.90 & 0.9 \\
\hline Acceptable & $<5$ & $<0.05$ & 0.9 & 0.9 & 0.9 & 0.9 & 0.9 & 0.9 \\
\hline
\end{tabular}

\section{LIMITATIONS OF THE STUDY}

The palapable and nudging limitation could very well be the fact that lot more discussions happened in the field of online buyer behaviour, the ever changing relentless change in the growing tastes and preferences of consumer and these aspects are on a constant and into more reliable change happening with the increasing adaptation of technology, craving for intense information on a continual basis. 


\section{Ecommerce Policy Conundrum Disrupting Consumer Efficacy Euphoria and Ease are Becoming the Elucidated Predictors in The Emerging Lifestyle of Indian Online Purchasing Diaspora.}

Here the continual basis give rise to periodical reviewing of ties like loyalty and brand preference and trying to asymmetrically de-clutter the end-user perspectives(Baskaran, V., R. 2018).Adding it up is the sole criterion of bonding with the existing and emerging customers on futuristic needs and their fulfillment strategies. When buyer goes virtual it is quite evident the emotional components rule the state of mind inturn the decisional influences and choice and channelization are foregone conclusion. Using predictive behavioural analysis and machine learning algorithms days are not far off in which automated algorithms what we today call as shopbots will exactly predict and delivery will be made ready even before the buyer clicks the buy button. Is it getting more routinized response? Quite unlikely the opposite since much of the impulsive nature of the techno savvy online buyer comes more on a classical conditioning mode.

\section{CONCLUSIONS}

Stocking great GMV on the website should not be the deciding factor for mood swings and customer acquisition strategies but in reality for example Chinas leading online portal Amazon which was founded as Cadabra in 1994 by Jeff Bezos later renamed later as Amazon in 1995 and amazon with the market cap of US $\$ 450$ billion and alibaba has market cap of US $\$ 270$ billion but interestingly GMV of alibaba is US $\$ 750$ billion and GMV of amazon is US $\$ 250$ billion. Our Indian Ecommerce market should reach between these two major players by the virtue of number of active internet users and to facilitate that process this study of efficacy euphoria and ease is attempted where the internet commerce industry has just got over its embryonic to growth mode and what concerns are faced is equally important and decisive from the liberal FDI and tax policies of Indian government which will shape the burgeoning success of this industry which crossed lots and lots of topsy turvy hiccups and finally may poised to reach the tipping point by 2025 .

\section{REFERENCES}

1. Anderson, J. C., \& Gerbing, D. W. (1991). Predicting the performance of measures in a confirmatory factor analysis with a pretest assessment of their substantive validities. Journal of applied psychology, 76(5), 732.

2. Baskaran, V., R. (march2018). Indian Online Marketspace Leadership Innovations and Gullible Enduser Perceptions. International Journal of Research in Economics and Social Sciences (IJRESS), 8(3), 14-24.

3. Byrne, B. M. (2016). Structural equation modeling with AMOS: Basic concepts, applications, and programming. Routledge.

4. Ganesh, J., Reynolds, K. E., Luckett, M., \& Pomirleanu, N. (2010). Online shopper motivations, and e-store attributes: an examination of online patronage behavior and shopper typologies. Journal of retailing, 86(1), 106-115.

5. Gefen, D., Karahanna, E., \& Straub, D. W. (2003). Trust and TAM in online shopping: An integrated model. MIS quarterly, 27(1), 51-90.

6. Gefen D and Straub D.W. (2004). Consumer trust in B2C e-commerce and the importance of social presence: Experiments in e-products and e-services. Omega, 32(6), 407-424.

7. Häubl, G., \& Trifts, V. (2000). Consumer decision making in online shopping environments: The effects of interactive decision aids. Marketing science, 19(1), 4-21.

8. Jensen, J. M. (2009). Travellers' intentions to purchase travel products online: The role of shopping orientation. In Advances in tourism economics (pp. 203-215). Physica-Verlag HD.
9. Jusoh, Z. M., \& Ling, G. H. (2012). Factors influencing consumers attitude towards e-commerce purchases through online shopping. International Journal of Humanities and Social Science, 2(4), 223-230.

10. Katawetawaraks, C., \& Wang, C. L. (2013). Online shopper behavior: Influences of online shopping decision.

11. Koo, D. M., Kim, J. J., \& Lee, S. H. (2008). Personal values as underlying motives of shopping online. Asia Pacific Journal of Marketing and Logistics, 20(2), 156-173.

12. Lee, G. G., \& Lin, H. F. (2005). Customer perceptions of e-service quality in online shopping. International Journal of Retail \& Distribution Management, 33(2), 161-176.

13. Maicas J.P, Polo Y and Sese J (2006) The impact of customer relationship characteristics on customer switching behavior, Managing Service Quality, Vol. 16 No. 6, pp. 556-574.

14. Miyazaki, A. D., \& Fernandez, A. (2001). Consumer perceptions of privacy and security risks for online shopping. Journal of Consumer affairs, 35(1), 27-44.

15. Morgan, Robert M. and Shelby D. Hunt (1994) The Commitment-Trust Theory of Relationship Marketing, Journal of Marketing, 58 (July), 20-38

16. Narang, R., \& Trivedi, P. (2016). Challenges and opportunities of e-tailing in emerging economies. In E-retailing challenges and opportunities in the global marketplace

17. Overby, J. W., \& Lee, E. J. (2006). The effects of utilitarian and hedonic online shopping value on consumer preference and intentions. Journal of Business research, 59(10-11), 1160-1166.

18. Palmatier, R. W., Jarvis, C. B., Bechkoff, J. R., \& Kardes, F. R. (2009), The role of customer gratitude in relationship marketing. Journal of marketing, 73(5), 1-18.

19. Prasad, C. J., \& Aryasri, A. R. (2009). Determinants of shopper behaviour in e-tailing: An empirical analysis. Paradigm, 13(1), 73-83.

20. Rafiq M., Fulford, H and Lu, X (2013). Building customer loyalty in online retailing: The role of relationship quality. Journal of Marketing Management, 29(3-4), 494-517.

21. Singh, J. (2017). Online Shopping: A study of buying behaviour of the consumer. International Journal of Engineering Technology and Computer Research, 5(3).

22. Wolfinbarger, M., \& Gilly, M. C. (2001). Shopping online for freedom, control, and fun. California Management Review, 43(2), 34-55.

23. Yu, T. K., \& Wu, G. S. (2007). Determinants of internet shopping behavior: An application of reasoned behaviour theory. International Journal of Management, 24(4), 744.

\section{AUTHOR PROFILE}



Dr R. VijayaBaskaran Principal East point college of Higher Education at Bangalore is a leading group of academic institutions having widespread presence in various spheres.The author has 33 years of academic, industry and research experiences helmed his rich background as Director B-School, Professor in various institutes who made a significant role in management teaching. Having published around 24 papers in leading national and international journals authored a book too. 